\section{Ulikt jobbmønster hos kvinne og mann}

Færre kvinnelige enn mannlige leger har bistillinger. Menn som har hovedjobb i det private næringsliv, har ofte flere jobber jo flere barn de får. Kvinnelige leger i samme situasjon gjør det motsatte, viser en nylig avholdt doktorgrad.

- Jeg viser i avhandlingen min at det er kjønnsforskjeller i legers valg av arbeidssted. Det er interessant å se at mannlige leger har større sannsynlighet for å ha bistillinger jo flere barn de får, sier Ragnhild Røhme Fjærtoft til Tidsskriftet. Hun disputerte i januar 2014 med avhandlingen Multiple job holding and labour decisions among Norwegian medical doctors som utgår fra Økonomisk institutt ved Universitetet i Oslo.

\section{Legers valg av arbeidssted}

Hovedtemaet for avhandlingen er norske legers valg av arbeidssted. I avhandlingens første to artikler retter Fjærtoft søkelyset mot bistillinger blant leger, mens siste del handler om å finne grunnlag for at psykiatere skal velge å jobbe i offentlige institusjoner i spesialisthelsetjenesten. Fjærtoft har selv konstruert datasettet basert på Helsepersonellregisteret, Arbeidstakerregisteret og ligningsinformasjon og demografiske opplysninger fra blant annet Statistisk sentralbyrå. Dataene dekker perioden 1999-2007 og omfatter rundt 24000 leger.

\section{Betydning for offentlig helsetjeneste}

Tilbudet av offentlige helsetjenester avhenger av tilgangen på leger og deres valg av arbeidssted. Kunnskap om hva som er av betydning for leger når de velger arbeidssted, kan være viktig i utformingen av arbeidsmarkedspolitikk for leger. Resultatene indikerer at både demografiske og institusjonelle faktorer har betydning - som kjønn, alder, antall barn/personer i husholdningen, spesialisering, sivil status, helseregion og antall potensielle arbeidsgivere.

\section{Bistillinger}

Avhandlingen viser at når leger er stilt overfor valget mellom bistilling eller ikke, har mannlige leger større sannsynlighet enn sine kvinnelige kolleger for å ha to eller flere stillinger. Bistillinger er dessuten mest utbredt i de mindre sentrale delene av landet. Totalt var andelen leger med bistillinger $38 \%$ i 2007. Fordelt på kjønn hadde $42 \%$ av de mannlige legene bistillinger, mens tallet for de kvinnelige legene var $32 \%$.

\section{Psykiateres jobbvalg}

I avhandlingens tredje artikkel viser Fjærtoft at psykiaternes jobbvalg varierer om de bor i hovedstadsregionen eller i andre deler av landet. Kvinnelige psykiatere som bor utenfor Oslo og Akershus, har større sannsynlighet enn sine mannlige kolleger til å være ansatt i offentlige institusjoner i spesialisthelsetjenesten, som psykiatriske sykehus, DPS eller somatiske sykehus, mens menn i hovedsak jobber som avtalespesialist, eller som privatpraktiserende uten avtale.

\section{Gunn Marit Seberg}

Tidsskriftet

\section{Beste oversiktsartikler i Tidsskriftet 2013}

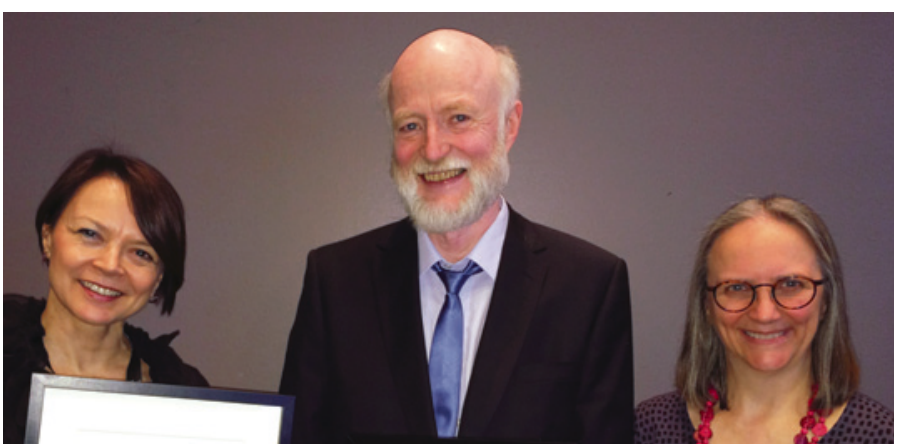

Fra venstre Hebe Désirée Kvernmo, Odd Jarle Kjørstad og Dagny Faksvåg Haugen

Pris for beste oversiktsartikkel 2013 gikk til Nekrose i fingre og toer etter lokalbedøvelse med adrenalin - en vandrehistorie? av Vilhjalmur Finsen (f. 1946).

På andreplass kom Hjarte-lunge-redning til kreftpasientar i palliativ fase av Odd Jarle Kjørstad (f. 1952) og Dagny Faksvåg Haugen (f. 1957), mens tredjeprisen gikk til Behandling av medfødte sammenvokste fingre av Hebe Désirée Kvernmo (f. 1961) og Jan-Ragnar Haugstvedt (f. 1954).

Prisene ble delt ut på møtet for de faglige medarbeiderne, som $\mathrm{i}$ år ble avholdt i Bergen 10. mars 2014.

Vilhjalmur Finsen var ikke til stede under møtet, men de øvrige prisvinnerne holdt interessante innlegg under møtet.

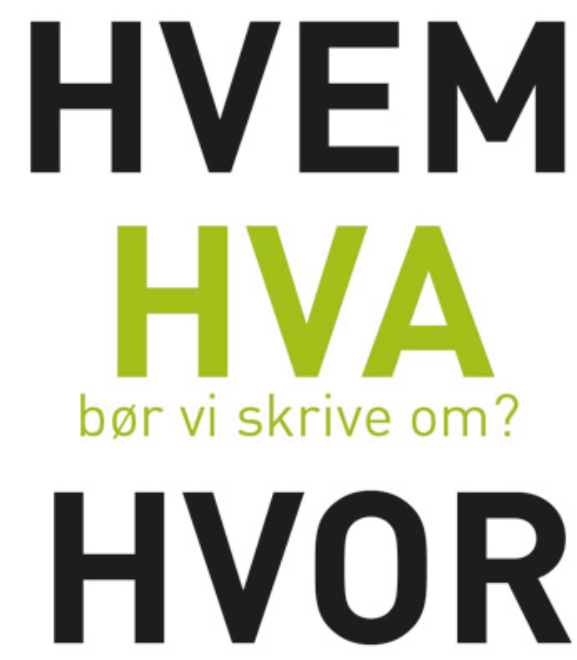

Tips oss om ditt legeliv

tidsskriftet@legeforeningen.no 